University of Tennessee College of Law

Legal Scholarship Repository: A Service of the Joel A. Katz Law Library

UTK Law Faculty Publications

6-2013

A Glass Half Full Look at the Changes in the American Legal

Market

Benjamin H. Barton

Follow this and additional works at: https://ir.law.utk.edu/utklaw_facpubs

Part of the Law Commons 


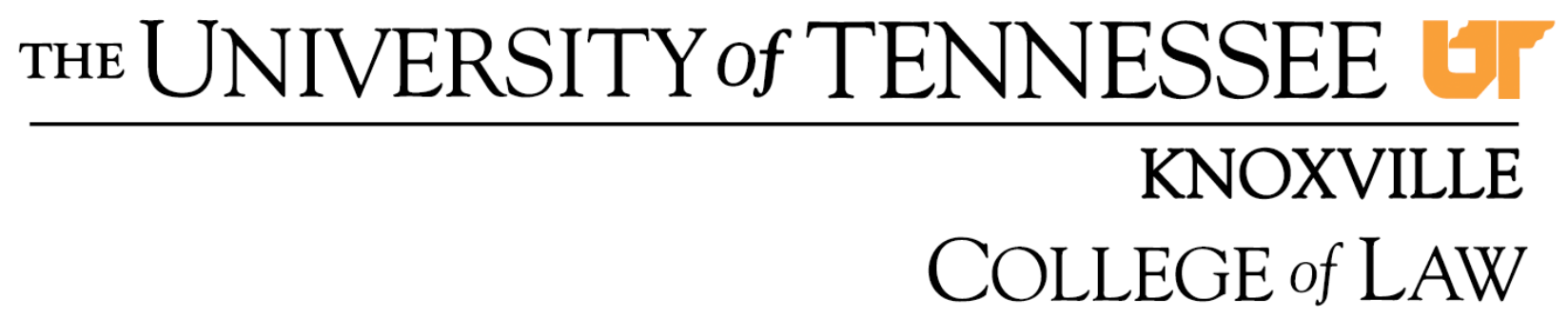

Legal Studies Research Paper Series

Research Paper \#210

June 2013

\title{
A Glass Half Full Look at the Changes in the American Legal Market
}

\author{
Benjamin H. Barton \\ Do not cite without author's permission \\ Copyright (C) 2013 \\ This paper can be downloaded without charge \\ from the Social Science Research Network Electronic library at: \\ http://ssrn.com/abstract=2054857
}




\section{A Glass Half Full Look at the Changes in the American Legal Market}

Benjamin H. Barton ${ }^{1}$

The American legal profession finds itself in the midst of dizzying changes. What was once viewed as a brief downturn now looks like a much more substantial restructuring and downsizing. The main commentators on these trends have been those most likely to be affected: law professors and corporate lawyers, and they have largely presented these trends as disastrous. This Essay argues that while these changes will be painful in the near term, they will prove beneficial overall.

The obvious reason for optimism is that America will be significantly better off if we spend less on legal services. Whatever else the future holds it seems likely that legal services will be more widely available to more people at lower prices. This trend starts at the top with corporate law firms and bubbles up from the bottom with LegalZoom and other online forms providers and will eventually reach the entire market. Expenditures on law are typically just transaction costs and everyone is better off when transaction costs shrink. If you have enjoyed the digital revolution in music or photography, you will likewise enjoy the legal market of the future. Legal services will be cheaper, more accessible AND better. These changes are bad for lawyers in the same way digital photography was bad for Kodak. Nevertheless, it is outstanding news for the country as a whole.

Less obviously, the trends identified in Larry Ribstein's "Death of Big Law" and the ripple effect through law schools will, ironically, lead us to a leaner, happier profession. For years the hope of securing a job in BigLaw, the easy availability of student loans, and the misperception of what lawyers do and what law school is like have drawn many ill-suited individuals into law. This has had a number of deleterious effects on those individuals and on the practice as a whole. Current market forces and news coverage, however, will eventually result in a profession staffed by individuals who chose law despite a substantial headwind, rather than because they did not know what else to do and they thought it would guarantee a high salary for life. This will make the profession as a whole healthier than it has been in years.

\footnotetext{
${ }^{1}$ Professor of Law, University of Tennessee College of Law. B.A. 1991, Haverford College; J.D. 1996, University of Michigan. First and foremost I want to thank Larry Ribstein for his friendship and support over the years. The scholarly endeavor can be a lonely one, but Larry was a kind and eversupportive fellow traveler. I respectfully dedicate this essay to his memory.

I would also like to thank Brannon Denning and Glenn Reynolds, who talked many of these ideas out with me, Bruce Kobayashi, Bill Henderson, Dan Currell, Todd Henderson, Gillian Hadfield, Indya Kincannon, Jeff Hirsch, Alex Long, Jennifer Hendricks, the University of Tennessee College of Law for generous research support, and the Honorable Diana Gribbon Motz.
} 


\subsection{Introduction}

Charles Dickens wrote Bleak House as a serial in the 1850s and published it as a whole for the first time in 1853 [1]. It is a blistering assessment of the English Chancery system and remains one of the most trenchant critiques of the common law system of civil justice. It is also, like most Dickens serials, a ripping good yarn.

Given the bewildering series of technological and societal changes over the last 160 years, there is something remarkable about Dickens' portrait of lawyers in Bleak House: it is utterly familiar to a modern reader. Chapter One takes us on a tour "In Chancery" and we see lawyers arguing a motion in Jarndyce and Jarndyce. In Chapter Two, Lady Dedlock and Sir Leicester meet with their solicitor Mr. Tulkinghorn for a status report on the same case.

Bleak House portrays a legal profession little changed from then to now. Law in 1850s England was an individualized and bespoke ${ }^{2}$ professional service that consisted of paying a lawyer for his time, sometimes in court, sometimes in consultation, sometimes in drafting documents and sometimes in research. Legal practice has changed in tools (computers notably) and in scope (today's big American law firms are without historical parallel), but not in kind. Law may have changed less than any other area of the economy between 1850 and today. The same basic product is being sold and the same basic service is being performed.

Law is notoriously resistant to change, and legal practice and American law schools have likewise proven unusually resistant to adaptation over the last century.

\footnotetext{
2 Bespoke was originally a tailoring term, denoting custom made clothes for individuals. It has since come to be used more broadly to refer to any individualized, custom service. Susskind [2] uses the term to describe the bulk of the legal work of British solicitors and barristers.
} 
Nevertheless, none of us dodge the reaper forever. The industrial revolution brought mass production to manufacturing and the information revolution has seen knowledge workers replaced by computers. In multiple areas of the economy computers now handle work once done on an individualized basis by highly paid professionals.

The pattern for these changes began in the industrial revolution and continued in the information revolution. Bespoke work done by individuals for other individuals on a custom basis are replaced by standardized and then commoditized replacements, mass produced, and much, much cheaper. The total number of people needed to create the good goes down, as does the average wage earned by those in the industry. The few at the top who control the process or design the product, however, make much more than any former provider of bespoke services ever could.

\subsection{BigLaw Begins to Suffer, Catching Up with Small Firm and Solo Practitioners}

Like other areas of the economy once dominated by bespoke services, American lawyers face a bewildering set of challenges. The changes are sweeping over small firm and solo practitioners as well as large corporate law firms. Larry Ribstein's The Death of Big Law [3], Glenn Harlan Reynolds' Small is the New BigLaw: Some Thoughts on Technology, Economics, and the Practice of Law [4], and William Henderson's From Big Law to Lean Law [5] in this issue, lay out the challenges facing large American law firms. American law firms experienced a period of strong and uninterrupted growth from the 1950s through 2008, growing in size, and outpacing inflation in revenue, profits, and profits per partner. These law firms now face flat 
or shrinking revenue growth. Corporations are increasing the size of their in-house legal departments and are relying more on outsourcing, insourcing (handling more legal work in house) and virtual law firms $[3,5]$.

But at least BigLaw had salad days leading up to 2008. Historically and currently the majority of American lawyers have worked in small firms or as solo practitioners, largely representing individuals or small businesses on a mix of legal issues [6,7]. These lawyers shared some of the post-World War II boom for lawyers, riding a wave of profitability through 1990. Between 1950 and 1978, the income of all those involved in producing legal services increased by 544 percent and personal consumption expenditures for legal services, which had barely increased at all between 1929 and 1940 (from $\$ 402$ to $\$ 423$ million, an annualized growth of 0.5 percent) jumped to $\$ 8.6$ billion in 1976 for annualized growth of 51 percent [7]. The proportion of American gross national product (GNP) spent on legal services tripled between 1967 and 1992 [7]. The number of lawyers grew from 250,000 to nearly 850,000 [8]. Between 1975 and 1990 lawyer earnings grew at 6.6\% annually, rising almost every year and generally outrunning inflation [9].

Since 1990 the fates of small firm and solo practitioners and large law firms have diverged substantially. From 1990 to 2004 there were three recessions for lawyers and the overall growth was slower, under 2\% per year [8]. Many small firm and solo practitioners have seen flat or shrinking real incomes over this period [10]. The average income of a solo practitioner in the United States in 2004 was less than $\$ 46,000$-about a 30 percent decline, in real dollars, compared to the previous generation [8]. 
The salary distributions for new law graduates show this trend quite crisply. As late as 1996 the chart roughly approximated a bell curve where the median starting salary $(\$ 40,000)$ was quite close to the top of the curve and the salaries at the high end were roughly twice the median salary [11].

By 2006, starting salaries had separated into two humps, one for corporate lawyers and the other for everyone else, divided by a significant gulf:

\section{FIGURE 1}

The top of the lower curve is well below the median salary and few lawyers actually earn the median salary. The BigLaw salaries are between three or four times more than the salaries for everyone else, meaning that any students who attended law school and planned on a BigLaw job will be sorely disappointed with their eventual salary.

The 2010 chart is even more pronounced, with a sharp peak at $\$ 160,000$ and everybody else between 40,000 and 65,000 [12].

\section{FIGURE 2}

These salary distributions show a very unusual profession. Salaries more typically resemble a bell curve, with the height of the curve near the mean/median salary. ${ }^{3}$ Since 2000 , however, starting lawyer salaries have divided into two very separate groups. The great bulk of new law graduates (and of practicing lawyers) work on the left side of the double hump. Inflation-adjusted wages for these

\footnotetext{
3 As a comparison point, consider the starting salaries for business school graduates. In 2009 Businessweek published graphs for starting salaries for the top 30 business schools and each of them resembled a bell curve with the peak near the median salary [14]. Likewise, Winston and Maheshri's study of lawyer's fees in this issue shows a rough bell curve [15].
} 
lawyers have either held steady or declined slightly over the last 40 years, with wages for solo practitioners seeing a 30\% decline in real dollars over that period.

\subsection{Glass Half Full}

With the current slowdown in BigLaw, however, law schools, corporate lawyers and solo practitioners alike are facing hard times. The main commentators on these trends have been the parties most directly affected: lawyers and law professors. Since these are two of the groups most likely to suffer under the new market conditions, commentary on these trends has run from concerned to outright panic [17-20]. And these worries are not ill-founded: life is very likely to get significantly worse for the majority of law professors, corporate law firm partners and associates in the near term and for the foreseeable future.

There are, however, significant advantages to the current state of affairs that should not be overlooked. The obvious advantage is that America as a whole will be significantly better off if we spend less on legal services and Part 2 of this article argues that whatever else is coming in the future it seems likely that legal services will be more widely available to more people at lower prices. This trend starts at the top with corporate law firms and bubbles up from the bottom with LegalZoom and other forms providers.

A reallocation of human resources away from law will also be beneficial to society as a whole, the legal profession, and the students themselves. Society benefits because too many bright young people have been going to law school, rather than potentially choosing more societally beneficial work. This is changing. 
Applications to law schools are in free fall, with a notable absence of the very best applicants (based upon LSAT and GPA) [21,22].

This trend benefits the legal profession and law students themselves because some or many of the law students from five years ago did not belong in law schools. They came because it was a default choice for smart college graduates who were bad at math but still wanted a safe career with a large salary. Rampant unhappiness in the legal profession and the fact that there are many more law school graduates than available law jobs are both evidence that too many of the wrong people have found themselves in the legal profession. Going forward, current law students will think carefully before entering law school. They will also reduce borrowing, freeing them to take jobs they like rather than jobs that repay loans.

The slow down in BigLaw and the ripple effect through law schools will ironically lead us to a leaner, happier profession and group of law students. Current market forces and news coverage will result in a profession staffed by individuals who chose law despite a substantial headwind, rather than because they did not know what else to do and they thought it would guarantee a high salary for life. This will make the profession as a whole healthier and happier than it has been in years. 2.1 In the Future, Most Legal Work Will Be Cheaper, Some Work Will Be More Expensive and Most Lawyers Will Be Poorer

This section details the pressures on American lawyers that are coming from above, below and the side. From above, BigLaw faces the challenges described by Henderson [5], Reynolds [4] and Ribstein [3]. From below, LegalZoom and Rocketlawyer present a powerful competitor to small firm and solo practitioners today, and potentially to BigLaw tomorrow. Small firm and solo practitioners also 
face competition from the side as displaced BigLaw lawyers and a flood of new and underemployed law graduates enter the market.

\subsection{BigLaw Faces Pressure from Above}

Ribstein's Death of Big Law [2] is the meisterwerk in this area, so I will only add a few observations here. As Ribstein noted, BigLaw faces slow or stagnant growth, higher leverage, fewer partners, increased lateral movement, and slow hiring out of law schools. The collapse of Dewey \& LeBouef is the poster child for these issues, but the concerns run much more deeply than a recessionary slowdown.

Henderson [5], Reynolds [4] and Ribstein [3] make a powerful case that the primary reason for the existence of BigLaw is reputational bonding: clients seek out large corporate law firms because these firms have presumably done the work to select the most able lawyers for the most complicated work. Clients can thus hire a firm by reputation and trust that their work will be handled appropriately. Because law is a credence good, firm reputation plays an especially powerful role in the corporate legal market [3].

Nevertheless, as information becomes more freely available and corporate clients become increasingly concerned with both the price of legal work and measuring its effectiveness, the reputational power of many law firms are waning $[3,4]$. The behavior of law firms seeking ever-higher profits has also contributed: increasing the associate to partner ratio and relying on lateral movement all erode firm quality control and concomitantly, reputation.

The collapse of Dewey \& LeBouef is telling because it shows how shallow reputational bonding really is. If a group of partners in a law firm decide that their 
book of business is worth more elsewhere, they will leave. If the firm seems endangered, a mass exodus is likely. If a tipping point is reached, firms that have existed since the 1920 s or earlier can collapse almost overnight. The really scary part of the Dewey \& LeBouef collapse was that there was so little to the firm. It was basically a building filled with lawyers. When the lawyers bailed, the firm itself was worth almost nothing.

The waning power of reputational bonding tells part of the story, but corporations have also changed their behavior. Corporations have brought increasing pressure on their legal departments to lower costs and demonstrate value in legal expenditures. This has resulted in increased expenditures on outsourcing, insourcing, virtual law firms and other non-BigLaw ways of handling legal work [5].

In this issue Daniel Currell and Todd Henderson argue that the death of BigLaw has been greatly exaggerated, pointing to higher fees, even in the teeth of the recent recession [23]. Nevertheless, their analysis also shows that corporations are spending less on outside counsel overall [23].

This seeming incongruity actually helps explain the challenges facing BigLaw quite well. There is still, and will always be, legal work that is sufficiently important to a company (so called "bet the company" litigation or a major merger are examples) that BigLaw can continue to charge more and more for. This explains rising fees.

Nevertheless, much of the work currently done by BigLaw (discovery or due diligence are excellent examples) is not as important and more easily outsourced or 
mechanized. This work is migrating away from BigLaw and to cheaper providers. This explains the lower overall expenditures.

Over time the truly valuable work will be concentrated in fewer and fewer firms and handled by fewer lawyers. This process has already begun, as Currell and Henderson's article [23] establishes: the bulk of the rise in hourly rates has come from the highest grossing partners already. Coupled with the shrinkage in the number of equity partners and the downward pressure in the lateral market noted in William Henderson's paper in this issue [5] one can see a market where the most sought after lawyers and firms continue to profit while the rest slowly drift back towards the pack.

\subsection{LegalZoom and Others Bring Pressure from Below}

The emergence of LegalZoom and other on line purveyors of legal forms also helps explain the Currell and Henderson [23] incongruity. Solo and small firm practitioners operate in a manner that would be familiar to their counterparts from 1962 and probably even 1912 . They individually represent small businesses and individuals on a mix of different matters from divorce, to criminal charges, to incorporation. These jobs have been made easier by computers and forms, but as a general rule these lawyers make a living offering one on one services to individual clients. ${ }^{4}$ Bespoke business models have not fared well since the industrial revolution, as factories and large organizations replaced cottage industries [24].

\subsubsection{Disruptive Technologies}

\footnotetext{
4 This description generally applies to BigLaw as well. Those lawyers have taken advantage of economies of scale by forming large law firms, but these law firms just service bigger cases for bigger clients. They still resist routinization of legal work.
} 
Clayton Christensen's theory of disruptive technologies helps explain the mechanism of these changes [25]. Christensen argues that disruptive technologies arise from below: the competitors start by focusing on a segment of the market that is lower margin, frequently offering worse services to these customers [25].

The producers at the top of the market who are providing the higher margin goods are at first unconcerned. Why would they worry about losing the low end of the market when they are dominating the higher margin work? But the producers in the lower end of the market eventually master the low margin work and gradually start to compete for the higher margin work.

Christensen offers multiple examples, but the steel industry is particularly evocative. Up through the 1970s massive integrated steel companies made most of the world's steel. But in the 1960s, a new technology arrived. So called "mini mills" could melt scrap metal in comparably tiny electric furnaces to create steel. Mini mills made steel $20 \%$ more cheaply than large integrated mills. But, because they worked from scrap, the quality was at first much poorer than the steel from the integrated mills, so the integrated mills continued to dominate the market.

The mini mills competed at first by focusing on rebar, because rebar had few specifications and was the very bottom, lowest margin part of the steel market. The integrated mills were happy to abandon the rebar market to the mini mills because it was a low margin, dog-eat-dog market. In fact, when the integrated mills abandoned rebar, their gross-margin profitability actually improved, because they left a lower margin market to focus on higher margin ones. Nevertheless, as the mini mills mastered rebar production and survived a price war at the low end of the 
market they eventually moved on to the next tier of the market, climbing up each rung until they eventually drove the integrated mills out of business.

The problem with disruptive technologies is that a rational supplier at the top of the market will have no incentive to compete with them, or even really pay attention to them at all. Why? Christensen notes three reasons:

First, disruptive products are simpler and cheaper; they generally promise lower margins, not greater profits. Second, disruptive technologies typically are first commercialized in emerging or insignificant markets. And third, leading firms' most profitable customers generally don't want, and indeed initially can't use, products based on disruptive technologies. By and large, a disruptive technology is initially embraced by the least profitable customers in a market. Hence, most companies with a practiced discipline of listening to their best customers and identifying new products that promise greater profitability and growth are rarely able to build a case for investing in disruptive technologies until it is too late. [25 at $\mathrm{xx}]$.

William Henderson has applied Christensen's work to the legal market, focusing on how outsourcing, computerization, and alternative delivery law firms like Axiom and Clearspire PLLC may become disruptive to BigLaw. Henderson includes a modified chart [26] to show how these innovations might affect BigLaw:

Figure 3

Henderson focuses at the top of the market and at firms like Axiom and Clearspire that are alternatives to BigLaw, but not total replacements of BigLaw.

\subsubsection{LegalZoom}

The lower end of the market is already seeing such technologies though, most notably in the form of LegalZoom and Rocketlawyer. These disruptive technologies have already begun to encroach upon, and may eventually cripple, the business of solo and small firm practitioners. 
Two refugees from BigLaw and an Internet entrepreneur launched LegalZoom.com in 2001 [27,28]. Its mission is to offer "assistance to individuals and businesses preparing online legal documents, including trusts, divorces, corporations, and copyrights." Wills were also offered, although original CEO Brian Liu thought most Americans would avoid making them because of the time and costs involved.

As predicted by Christensen, initially lawyers and bar associations paid little attention to the provision of legal services via the Internet. It consisted of chatboards offering pretty general advice and sites like LegalZoom selling various legal forms. The forms themselves were at first not very sophisticated and were very inexpensive. ${ }^{5}$ From 2001 until the late 2000s LegalZoom (and other sites) went about building their businesses and improving their forms and software with little notice or attention from the organized bar.

Given that every state in the union has rules or law against the unauthorized practice of law ("UPL") [29], this initial acquiescence is rather puzzling. One answer is that the Texas Bar Association had early success in barring a similar, off-line program called "Quicken Family Lawyer" as the unauthorized practice of law, only to be briskly overruled by the Texas legislature [30]. Lawyers may have thought that pressing their case against LegalZoom might make the situation worse.

LegalZoom and other on-line forms providers present a strange UPL case. ${ }^{6}$

State bars have long allowed the publication of "forms books" despite the UPL

5 LegalZoom still charges as little as $\$ 69$ for a will or $\$ 99$ for articles of incorporation [27].

6 Gillian Hadfield [31] offers an outstanding discussion of how the UPL restrictions affect computerized provision of legal services and choke innovation. 
strictures, but state bars have generally drawn the line at the provision of advice along with forms $[32,33]$. The hybrid nature of LegalZoom as an interactive forms system may further explain bar association's initial reticence.

Another answer, and the answer suggested by Christensen's work, is that lawyers were unconcerned when LegalZoom started because LegalZoom was not really competing with private lawyers. LegalZoom is the classic Christensen disruptive technology - it started by servicing the lowest margin part of the market and has gradually inched its way up.

American lawyers currently do very little paid work for the poor and middle class. There are multiple studies showing unmet needs for legal services among the poor and middle class. Hadfield's article in this issue offers an outstanding review of this literature [34]. Part of this is because even relatively inexpensive lawyers charge quite a bit by the hour, and for even moderately complicated work those hours add up. Some of it is that given the ever-growing expense of undergraduate and law school educations, more lawyers compete over more remunerative work and eschew the lower end of the market.

Regardless of the reasons, the staff and lawyers in solo practitioner or small firm offices spend a great deal of time explaining to potential customers that they cannot afford legal services, or explaining why it is so expensive to incorporate a company or to file and prosecute a divorce. In 2001, when LegalZoom started out, anyone willing to incorporate their company or write their will on the internet was very unlikely to be able to afford a lawyer anyway. LegalZoom thus was not in direct 
competition with lawyers, it was merely soaking up a portion of the market lawyers had long since unilaterally abandoned.

The first wave of clients LegalZoom grabbed were no loss at all. Any potential client who could not afford a "real lawyer" and would settle for a random form that (at first) might not even be particularly suited to their state or jurisdiction was hardly worth losing any sleep over. LegalZoom made no attempt, nor could it because of UPL, to snatch any in-court litigation work, which meant that large swaths of small firm practice (like divorce, child custody, small commercial lawsuits, etc.) were still unreachable.

Over time, however, LegalZoom started to climb the ladder and lawyers and bar associations started to notice. Estate planning lawyers have taken notice first (which is ironic given LegalZoom's original reticence on offering wills). Two 2010 articles by wills and estates practitioners are sharply critical of LegalZoom for the unauthorized practice of law and seem quite concerned about the threat to their interests and a theoretical threat to the public $[35,36]$.

A lawyer in Missouri filed a class action suit against LegalZoom for the unauthorized practice of law; the case was settled before trial [37]. LegalZoom agreed to a payment and some unspecified changes in its business practices in return for the ability to continue operating in Missouri. The CEO of LegalZoom stated that they settled the suit "with little change in [the] business, agreeing mainly to pay lawyers' fees." [27]

LegalZoom also settled a UPL investigation by the State of Washington by entering into a non-specific agreement and continuing to operate in the state [38]. 
Most recently, LegalZoom has brought pre-emptive suit against the State Bar of North Carolina, seeking a ruling that the site does not violate the ban on unauthorized practice [39].

LegalZoom has reacted to these bumps in the road in two ways. First, it has simply driven through them, getting bigger and more prevalent all the time. This is actually its most powerful tool. The larger, older, and more common LegalZoom gets, the less likely a court will find UPL and the more likely a legislature might overrule an adverse decision.

Second, LegalZoom has started offering a network of local attorneys to field calls from their customers. Forbes described the initiative as "effectively trying to buy off the enemy by setting up a network of local attorneys" [27]. These lawyers should be careful what they wish for, however. When knowledge work is commoditized or sold en masse by computers it inevitably becomes much, much cheaper.

Regardless of the UPL wrangling, LegalZoom has drawn some very serious venture capital and is poised to go public in the near future. According to Forbes, LegalZoom matches the venture capital checklist: it is a "disruptive model in a huge, decentralized business" and it "targets the high-volume, low-cost business of providing basic consumer and business documents." [27] Steven Harrick of Institutional Venture Partners described LegalZoom's appeal as follows: “The vast majority of the industry is still practicing law the old-fashioned way and overcharging customers." [27] 
LegalZoom has recently filed an S-1 form with the SEC in advance of a

presumed IPO [28]. The document contains the first widely available public data about LegalZoom, and as one might expect pre-IPO, it tells a rosy tale of growing revenues and future profits. First, the overview:

We developed our easy-to-use, online legal platform to make the law more accessible to small businesses and consumers. Our scalable technology platform enables the efficient creation of personalized legal documents, automates our supply chain and fulfillment workflow management, and provides customer analytics to help us improve our services. For small businesses and consumers who want legal advice, we offer subscription legal plans that connect our customers with experienced attorneys who participate in our legal plan network.

We have served approximately two million customers over the last 10 years. In 2011, nine out of ten of the approximately 34,000 customers who responded to a survey we provided said they would recommend LegalZoom to their friends and family. Our customers placed approximately 490,000 orders and more than 20 percent of new California limited liability companies were formed using our online legal platform in 2011. We believe the volume of transactions processed through our online legal platform creates a scale advantage that deepens our knowledge and enables us to improve the quality and depth of the services we provide to our customers. [28]

There are several frightening facts in here for lawyers. First, the statistic that $\mathbf{2 0 \%}$ of new LLCs in California in 2011 were LegalZoom generated is astounding. Likewise, the idea of 2 million costumers, with nearly a half a million just in 2011, is shocking. Many of these customers may not have been able to afford a lawyer in the first instance, but drafting LLC forms or incorporating businesses has long been a staple of legal practice. The loss of $20 \%$ of that business in California is not a promising sign for traditional lawyers. This is especially so because LegalZoom (and its competitors) seem unlikely to stall at only $20 \%$ of that business. 
Then there is the current revenue. Revenue was $\$ 103$ million in 2009 , $\$ 120$ million in 2010, $\$ 156$ million in 2011 , rising to almost $\$ 47$ million in the first three months of 2012. The firm turned a modest profit in 2011 and again in the first quarter of 2012, but it's the revenue growth and the projections suggested by the size of the market they are targeting, the $\$ 97$ billion that small businesses and consumers spent on legal services in 2011, that stands out.

As lawyers begin to recognize the threat of LegalZoom and to reflect on what LegalZoom does and does not do well, along with the likelihood that its products will improve, it will become clear that hiring a live lawyer to do individualized work for an hourly wage will become a somewhat iffy proposition, only for very flush clients or for very specialized work.

The greater worry for lawyers is that LegalZoom may soon be more than a cheap and acceptable alternative. LegalZoom may eventually be cheaper AND better. Right now lawyers are reaping the benefits of using interactive computer forms themselves [40], but LegalZoom may actually do a volume of business that will allow them to surpass the quality of individualized work. As LegalZoom puts it: "The high volume of transactions we handle and feedback we receive from customers and government agencies give us a scale advantage that deepens our knowledge and enables us to further develop additional services to address our customers' needs and refine our business processes." [28]

LegalZoom may be able to use its volume business to rapidly adopt new elements in its forms that have been approved by the courts or have proven especially effective. This could partially respond to Ribstein and Kobayashi's 
"private law production" problem [41]. If LegalZoom is able to really bear down on what is working best nationwide it could stay ahead of the curve in a way that an individual lawyer probably cannot, and could even affect the course of the law by bringing certain types of will codicils or LLC provisions to the fore.

\subsubsection{Today Small Firms, Tomorrow the World}

Christensen's work also suggests that BigLaw may want to more closely examine what LegalZoom is doing in the low end of their market. Bill Henderson tells a great story about Larry Ribstein presenting his Death of Big Law paper to a roomful of baffled and disbelieving managing partners. Their reaction to the proposed threat of LegalZoom has been similar: on line form-makers will never replace the high-end services they provide.

Is it unimaginable that LegalZoom could use its experience in drafting LLC and incorporation documents to begin stealing IPO or other higher end work? Many BigLaw deals work off of similar templates. Given the relative standardization of that work, BigLaw should certainly look beyond their near term competitors (in house counsel and alternative law firms) and consider the disruptive possibilities of interactive forms.

The planned LegalZoom IPO alone tells you volumes about what venture capitalists think about the potential for this approach. As LegalZoom begins to perfect the documents they offer, they will expand into other areas of legal work, until lawyers offer only true bespoke services: cases where the work is complicated, relatively unusual, and has important consequences. 
Just as was the case for BigLaw, a hardcore passel of bespoke legal work will remain. This will consist of the small firm versions of "bet the company" work child custody battles or contract battles that could sink a small business. Likewise, because of the structure of American courts and UPL protections, all in-court work will likely stay the province of lawyers or confused and overmatched pro se litigants. Outside of court it seems likely that any work that can be routinized or rationalized will be swallowed up, bringing brutal pressure from below.

\subsection{Pressure from the Side - More Lawyers Fight Over What's Left}

Not only are small firm and solo practitioners under pressure from below, the recent flood of law grads has brought pressure from the side. The ABA Section on Legal Education and Admissions to the Bar has kept detailed statistics on the number of law students at ABA accredited schools since 1963-64. ABA accredited schools now grant four times the number of JDs than they did 45 years ago [13]. In 1963-64 ABA accredited law school granted 9,638 JDs. In 1973-74 that number had risen to 22,342 , in $1983-84$, it was 36,389 , in $1993-94$ it was 40,213 , and in $2013-14$ is likely to top out over 45,000 .

Nevertheless, between 2004 and 2008 (before the great recession and the recent crash in legal markets) the Bureau of Labor statistics estimated that the number of Americans employed as lawyers grew by only $1 \%$, from 735,000 to 760,000 [42]. Over the same period that only 25,000 new lawyer jobs were created (academic years 2003-08), ABA accredited law schools graduated roughly 208,000 JDs, almost $28 \%$ of the number of existing lawyers [13]. In light of the post-2008 recession and including retirements and deaths, the legal market is estimated to 
generate fewer than 30,000 new jobs per year between now and 2016 [42]. Law schools seem likely to continue to graduate more than 40,000 a year.

Some of these graduates fail the bar and some choose jobs that do not require a law degree. Others, however, hang a shingle or form their own small firms and attempt to make a living in the super-competitive non-BigLaw private legal sector [43].

Similarly, BigLaw has shed quite a number of jobs over the last few years. In the 2010 National Law Journal survey of the 250 biggest American law firms reported "the biggest two-year drop" in law firm employment in the survey's 33year history. Law firms shed 5,259 lawyers in 2009 and another 1,402 in 2010, mostly associates. Some of these lawyers joined corporations and some found work in academia or government, but many of them joined smaller firms or started solo practices.

These displaced BigLaw associates and new graduates mean increased competition for the lawyers already practicing in these areas, as additional hungry mouths squabble over the work that remains. When more people compete over less work the cost of that work goes down for consumers and wages also decline.

\subsection{Law Schools Will Suffer as Well}

1950-1990 was a period of substantial growth in the earnings and number of lawyers, including small firm, solo practitioners and BigLaw. Law school growth followed along. From 1990 to 2007, small firm and solo practitioner earnings stagnated or actually lost ground against inflation. Law school growth continued regardless, with growth in the number of law students, the number of law schools, 
the number of ABA accredited law schools, tuition charged and the size of law faculties. If anything, the growth in law schools accelerated during the down period following 1990.

In 1953, there were 34,423 law students at 167 American law schools (126 ABA accredited) [13]. By 1983, there were 127,195 law students at 173 ABA accredited law schools. In 2011-12 there were 146,288 law students (down from 147,525 in 2010-11) law students at 201 ABA accredited law schools (up from 200 in 2010). In $2011 \mathrm{ABA}$ accredited law schools graduated 44,495 JDs; that number was 9,638 in 1963.

There was an even bigger boom in law school faculties. In 1947 there were 992 full-time law professors. By 1985-86 there were 4,881, and another 1,652 deans and law librarians, for a total of 6,533 [7]. In 2010-11 that total had grown to 14,987 [50]. Student-faculty ratios shrank greatly over this period as well [51]. Teaching loads went down, and salaries went up [52].

In order to pay for this additional staff there has been a steep increase in the cost of law school. Between 1985 and 2009, law school tuition rose 820 percent for in-state residents at public institutions and 375 percent at private institutions [52]. The average tuition for an in-state student at a public school in 1985 was $\$ 2,006$ [53]. In 2011, it was $\$ 22,116$. Out of state tuition at public schools averaged $\$ 4,724$ in 1985 and $\$ 34,865$ in 2011. Private school tuition rose from an average of $\$ 7,526$ to $\$ 39,184$. These increases in tuition occurred at the same time as the market for non-BigLaw lawyers peaked and fell backwards through the last 20 years. Law 
schools became much more expensive exactly as a legal education became less valuable to the students.

Student debt has also exploded [53]. A recent list of the top 10 law schools for student loan debt at graduation is shocking for the relative quality of the schools, the value of the degrees, and for the total indebtedness [54]:

\begin{tabular}{lcc} 
& Tuition & Average Student Debt \\
\cline { 2 - 3 } California Western School of Law & $\$ 42,600$ & $\$ 153,145$ \\
Thomas Jefferson School of Law (CA) & $\$ 41,000$ & $\$ 153,006$ \\
American University (Washington) (DC) & $\$ 45,096$ & $\$ 151,318$ \\
New York Law School & $\$ 47,800$ & $\$ 146,230$ \\
Phoenix School of Law & $\$ 37,764$ & $\$ 145,357$ \\
Southwestern Law School (CA) & $\$ 42,200$ & $\$ 142,606$ \\
Catholic University of America (DC) & $\$ 41,830$ & $\$ 142,222$ \\
Northwestern University (IL) & $\$ 51,920$ & $\$ 139,101$ \\
Pace University (NY) & $\$ 40,730$ & $\$ 139,007$ \\
Whittier College (CA) & $\$ 39,090$ & $\$ 138,961$
\end{tabular}

Between 1950 and 1990 the growth in the size and cost and debt load of American law schools was relatively rational. After all, between 1950 and 1990 the size of the profession, the percentage of GDP spent on legal services and the salaries of all lawyers grew relentlessly. So the supply of law grads and the cost of school made much more sense. Since 1990 the percentage of GDP spent on law and the real earnings of small firm and solo practitioners have fallen. Nevertheless, the 
number of law schools, the number of law graduates, the cost of school, and the average debt load have risen at an accelerating pace.

This behavior only made sense if law schools and students thought that law school was training students to work in BigLaw, where earnings rose over the same period. Nevertheless, the vast majority of American law students will never work in BigLaw, so there was a deep disconnect between law school, law students, and the actual legal market. Disgruntled law graduates started the ball rolling with so-called "scam blogs" decrying law school as nothing more than a bait and switch hustle. The complaints have since found larger purchase, with law professors like Brian Tamanaha [52] and Paul Campos [67] leading the way.

In the face of terrible news coverage and a slow down in hiring, applications to law schools have fallen sharply in the last few years. While American law schools will likely continue to be protected by the ABA accreditation process, some will go out of business if current application trends continue. Many of the schools that charge the most and saddle their students with the most debt are freestanding, private law schools with small endowments. The bulk of their costs are in tenured faculty, so cutting back will prove quite difficult.

\subsection{The Upshot}

As a result of computerization, data collection, outsourcing and insourcing American law will become more routinized and commoditized. When knowledge work becomes commoditized it becomes much, much cheaper.

Commoditization will also make the true bespoke work more valuable. As such, law will become much more of a "winner-take-all" market, as the creators of 
the leading commoditized legal products and the lawyers who are able to garner the work valuable or complex enough to require individualized work will profit greatly as others lose ground. Robert Frank $[45,46]$ has written at length of how this exact commoditization leads to a winner-take-all economy and the growth of the income gap between the rich and everyone else. One of Frank's favorite examples is one that should worry small firm lawyers facing down LegalZoom: the effect Turbotax has had on the accounting profession. The investors, designers and owners of Turbotax have grown wealthy indeed, while the accountants who once worked on those tax returns have grown poorer [45].

In court litigation and its related work will likely stay the domain of lawyers because of UPL and the fact that American courts remain remarkably hostile to pro se litigants [47]. At some point in the future courts may decide to streamline their processes or to become more pro se friendly [48], and if LegalZoom wanted to expand its business it would be wise to design and even operate model pro se courts. Nevertheless, in the near term that aspect of the lawyers' monopoly will remain unassailable.

The uptake of innovative technologies frequently follows an S shaped curve, where uptake rises slowly at first, followed by a sharp increase and then a leveling off [49].

Figure 4

Figure: Consumers adopting the technology are shown in blue, market share is shown in yellow.

The S shaped curve for innovation also suggests caution when predicting the technological future. Technological changes often come more slowly than we think. 
Some technological innovations that seem likely to succeed now will never get off the ground. Conversely though, the $\mathrm{S}$ shaped curve also suggests that successful innovations will likely bring unforeseen, profound, and transformative changes.

Technology and globalization have at last arrived at the door for private lawyers, whether in big firms or small. These changes suggest that the slowdown in the legal market is not recessionary, but structural, ongoing, and likely to accelerate. Lawyers and law professors should strap in, it is going to be a bumpy ride.

3.1 These Changes Will Challenge Lawyers and Law Schools, but Will Eventually Prove Advantageous to Society, the Legal Profession that Remains, and Law Schools

The good news is that the changes to the legal profession will have significant benefits for our country as a whole. Further, the lawyers and law schools that survive this turmoil will be stronger, better and happier.

\subsubsection{The Easy Case - Transaction Costs}

Transaction costs are the various costs associated with market transactions the cost of gathering information, contracting, and enforcing a contract are all examples. An analysis of transaction costs begins with the Coase theorem: so long as individuals act rationally and transaction costs are zero, legal rules are irrelevant to the efficient allocation of resources [55]. The Coase theorem assumes that the parties know the relevant economic variables; that wealth effects are absent; that competitive markets exist; and the cost of making transactions is zero [56]. Assuming that transacting is costless means that economic actors will naturally bargain in order to jointly maximize wealth. In a world without transaction costs, 
law will serve a relatively limited purpose, setting the initial rights around which parties can negotiate, but having little effect on the ultimate outcome [57].

We obviously do not live in a world where transaction costs are zero. Thus, Coase's work, and a great deal of the law and economics literature, is about how law, transaction costs, and efficiency interact [58]. As a general rule, law and economics scholars prefer legal regimes that minimize transaction costs and maximize private ordering and bargaining. As the actual market more closely approximates the transaction costless Coasian market, overall utility will be maximized as assets flow to their highest valued users [58]. Coase himself has long argued that the most useful aspect of his analysis is not the behavior of a transaction-cost-free society, but rather the importance of carefully considering how to minimize transaction costs through law and other means [58].

Everyone is better off when transaction costs shrink [59]. The money that had been spent on transaction costs can be spent on more productive activities and as the cost of transacting goes down more economically beneficial transactions will occur. Assets are more likely to be bargained over and to be transferred to their highest value users.

The work of lawyers is a quintessential transaction cost. Drafting contracts or IPO documents or litigating disputes are all transaction costs - market actors must pay these fees in order to settle disputes or complete sales or to head off future disputes [60]. When corporations spend less on legal fees they can give that money to shareholders or lower prices. When individuals can draft clearer and cheaper 
leases or wills or incorporation papers, the upfront costs of negotiation are lowered, and if the legal work is good, the likelihood of future litigation is also lessened.

It seems very likely that between computerization, the ongoing oversupply of new entrants into the market, outsourcing, and new models of service delivery the costs of legal services will inevitably fall. The argument that we will be better off with cheaper access to legal work is thus a simple Coasian syllogism: 1) markets work better and we are all better off when transaction costs are lower; 2) legal fees are transaction costs; 3) we are all better off when legal fees are cheaper.

There has been a long-term worry that Americans spend too much for legal services. A recent example is Winston, Crandall and Maheshri's First Thing We Do Let's Deregulate All the Lawyers [9]. The book builds its argument for deregulation of the legal profession on the "earnings premium" lawyers receive as a result of government regulation of entry (among other factors). The authors estimate that the U.S, spent $\$ 170$ billion on lawyers in 2004 , nearly $1.5 \%$ of the gross domestic product [9, at 20]. They then determined that $\$ 64$ billion of the $\$ 170$ billion was an earnings premium, i.e. lawyers being paid too much. The authors concluded that this premium was an "eye-popping $\$ 71,000$ per practicing lawyer - and that those premiums were widely shared among the legal profession" [9, at 55]. They also established that private lawyers working in law firms in the U.S. are paid much more than lawyers in other countries [9, at 27].

The retrenchment will change all of this. The legal sector has seen an absolute decline in expenditures between 2005 and 2010, but even before that 
period the legal sector as a percentage of gdp shrunk from over 2 percent in 1990 to under 1.4 percent by 2010 [62]. That trend will continue.

Currell and Henderson's paper in this issue [23] suggests a cloudier picture for the effect of cheaper law. Possibly we already have an efficient price for lawyers or maybe making lawyers cheaper will make society worse off, because lawyers impose costs that exceed their benefits [23]. Cheaper litigation costs could, in fact, make it more likely that litigation will be launched or maintained, a possible societal detriment.

Currell and Henderson do agree that non-litigation legal advice and work is more likely to be socially beneficial at a reduced price [23]. This is consonant with Gilson's [61] argument that much transactional lawyering is aimed at reducing overall transaction costs, and is thus a net societal benefit.

One comforting note for Currell and Henderson is that the lawyer's monopoly on legal work is strongest in litigation and weakest in private ordering. In court legal services are thus likely to be the least affected by computers and technology because of state law barring the unauthorized practice of law and American judges' hostility to pro se litigants. This will tamp down on any litigation explosion, as will the backlog of cases in state and federal courts.

The downward cost pressures of LegalZoom, outsourcing, and corporate insourcing will be most obviously seen and felt outside of the litigation arena. In fact, the changes buffeting the legal profession might be optimal for Currell and Henderson's concerns - because private ordering will become cheaper and much more widely accessible, while litigation will remain the primary province of more 
expensive lawyers. The law that will become cheaper through computers may actually lower litigation rates: if more people have wills, probate cases would be rarer. If more businesses have proper LLC documents, litigation over dissolutions or ownership should shrink. Thus, the costs of avoiding litigation are likely to shrink much faster than the costs of pursuing litigation.

Because the injured parties, lawyers and law professors, have led the way in commenting upon these trends, there has been a lot of handwringing. It is important not to lose the bigger picture - paying less for lawyers and for access to law will benefit everyone. When digital photography replaced film photography, Kodak was quite distressed, but everyone else was better off. Likewise, the music industry has not enjoyed the Internet era, but consumers have access to more recorded music at a lower price than ever before. If you have found yourself regretting these trends in the music and photography industries, feel free to decry the future of the American legal profession. If these trends have pleased you, you will likewise enjoy the legal market in the near term and going forward.

\subsubsection{The Easy Case - Access to Justice}

Corporations will not be the only beneficiaries. LegalZoom, new law grads, and unemployed lawyers going solo, will all combine to make law much more widely available and cheaper, especially to the middle class and the poor. Derek Bok famously noted that "[t]here is far too much law for those who can afford it and far too little for those who cannot" [63]. Hadfield's paper in this issue notes the scope of the problem through empirical calculation and a list of the many legal questions that confront the poor and middle class in our "law thick" society [34]. Other 
empirical studies support the claim that the poor and middle class are forced to go without needed legal services because of price [64]. Deborah Rhode's Access to Justice is a seminal work laying out how few Americans can afford needed services, from writing a will to seeking a divorce [65]. Rhode estimates that that 80 percent of civil legal needs are not met for the poor, and 40-60 percent of civil legal needs are not met for the middle class [65]. Further evidence is the flood of pro se litigation in American courts, frequently over complicated or important issues like child custody or divorce [48].

Bar associations and many advocates have argued for years that increased legal aid funding, required pro bono service or a civil Gideon right are the answers to these problems [66], i.e. more bespoke legal services by more government supported lawyers. The irony is that recent changes to the legal profession have been little discussed by the group of scholars and lawyers working on access to justice issues (Hadfield is a notable exception [31, 34]).

The coming changes will have two main effects and one speculative effect. First, just as with corporations, private ordering through law should become cheaper, more accessible and better for the poor and middle class. If more Americans have an up to date and legally enforceable will, probate actions will become more rare. If it becomes easier and cheaper to incorporate an LLC, more small businesses can move from sole proprietorships to more favorable entities, and so on.

Second, while the cost of hiring a lawyer to litigate in court will not decline as much as the cost of drafting legal documents, litigation costs will likely also fall. It 
seems unlikely that these costs will fall enough to reach all of the pent up demand, but middle class consumers should find it more affordable to litigate.

The speculative change is that the interactive, electronic forms approach of LegalZoom may inspire changes to the ways that courts interact with pro se litigants. As I have noted elsewhere, courts have traditionally been hostile to pro se litigants $[47,48]$. This need not be the case, however. As LegalZoom shows the power and efficacy of interactive forms for non-litigation uses, it may inspire changes in the pro se system. LegalZoom already does a good business in selling do-it-yourself divorces. Over time they may find it lucrative to help streamline the divorce process to include contested divorces or other, more complicated issues. If pro se courts become more litigant friendly and easier, the poor and middle class's lives would be benefitted immeasurably [48]. LegalZoom could also carve out an even larger, and more lucrative, chunk of existing legal work.

Computerization is thus on the verge of solving at least the outside-of-court access to justice problem by bypassing the legal profession altogether by providing much cheaper access to legal documents. As of right now, LegalZoom's forms and advice may not be as good as a live lawyer (although everyone knows a lawyer whose work is already worse than what LegalZoom provides), but over time they will continue to improve as experience guides changes to the programs and the forms. Regardless of comparative quality, LegalZoom and Rocketlawyer are already better than nothing, which is what most poor and middle income Americans can currently afford. 
Bar associations and lawyer apologists may argue that LegalZoom's services are so bad that they will prove more harmful than helpful to consumers. The dearth of consumer complaints against on-line providers, and the self-interest of bar associations claiming consumer protection, makes this worry quite speculative, however.

\subsubsection{A Reallocation of Human Capital from Law to Other Fields}

There is an apocryphal story that Judge Posner used to ask law students at the University of Chicago why so many smart people were coming to law school when they could be doing something more useful with their lives. Assuming that story is true, Posner will be pleased with recent law school application data. Applications as a whole are down, and especially among the best-credentialed applicants.

The total number of LSAT test takers has fallen for two straight years. Among the test takers that remain, the application yield has changed as well, with the highest LSAT scorers choosing to forego applying to law school [22]. The LSAT score to application chart below shows this trend quite clearly:

Figure 5

The median LSAT score is 2012 was 150. Thus, students who scored above the median on the LSAT are much less likely to have applied to law school than those who scored below, with the lowest scores the most likely to have applied.

Hopefully, section 2.4 convinced you that there are too many students paying too much to go to law school in pursuit of a shrinking number of less lucrative jobs. 
These students graduate disillusioned and saddled with a massive amount of nondischargeable debt only to find that there are roughly two American law graduates for every one opening for employment as a lawyer. If you are convinced that too many people are going to law school, you should also be persuaded that the current reverse brain drain of students not attending law school will benefit society.

Too many of America's best and brightest have chosen law school as a default option, as those students choose careers more suited to their tastes and proclivities, everyone will benefit. Angela Harris [68] states the issue quite succinctly: "The ever-rising salaries for the best and the brightest in large law firms means too many people going to law school instead of going into less lucrative but more socially beneficial careers; the losers include both the disappointed majority of lawyers who will never see six-figure salaries and society as a whole."

\subsection{The Harder Case - Law Students and Law Schools Will Be Better Off}

The current dislocation within the profession and law schools will be very, very hard. Losing jobs and shrinking salaries are not to be taken lightly at all and the likelihood that some law schools will close in the near term will be brutal for the faculty, staffs, administrations, and alumnae affected. Nevertheless, I feel confident that when the new normal has settled in we will all be better off.

Start with law graduates. There will be fewer of them. Because there are still many more law grads than jobs there will be a painful transition, but as matriculation decreases the problem should ameliorate.

Law school graduates should also have a better sense of the reality of the legal profession. Outlets as diverse as former Northwestern Law School Dean David 
Van Zandt and the ABA have noted that the cost of law school does not match up with the likely return [69]. Law schools themselves have faced lawsuits [70] and other pressure tactics [71] to force them to provide more realistic placement information to applicants. The reality should be sinking in to applicants that few law graduates will work in BigLaw, and of those who do, few stay for a lifetime. Hopefully these students will not think that the legal profession is a safe route to riches, because for the vast majority of lawyers it is not.

These graduates will have faced a tremendous headwind on their way to law school. Members of their family and their college classmates will have sent them Wall Street Journal articles and links to law school scamblogs, all of which begged them not to go to law school. Between their more realistic understanding of the cost of law school, their job prospects, the pain of repaying debt, and what most lawyers actually do and earn, the students that come to law school will really want to be there. They will be the students that have always wanted to be a lawyer, not history or english majors with nothing else in particular to do. These students will like law school more and will like practice more.

The experience itself will be cheaper and better. As fewer students apply to law school, there will be increased competition for students in terms of tuition and scholarships. The Wall Street Journal reports increased scholarship competition for applicants and increased cost haggling by incoming students [72].

As some law schools move away from competing over U.S. News rankings into the serious business of keeping the doors open and the lights on, the student experience will also likely improve. There will be pressure to decrease faculty 
scholarship (which is quite expensive) and to increase the teaching of useful legal skills.

The shrinkage of BigLaw and the general scarcity of legal employment may also engender a sense of perspective and gratitude for students who are able to secure employment. I have already noticed that students who get relatively low paying jobs as district attorneys, public defenders or legal aid lawyers are much less likely to grumble than in years past. These changes could lessen the divisiveness that comes from the double hump salary chart for new grads and may actually force the double hump back to a bell curve.

The downward pressure on costs and borrowing will also allow law students to choose jobs that they like, rather than jobs to repay loans. One of the long time arguments against the cost of law school and the size of student debt is the idea that idealistic students who came to law school to serve justice have been driven into the arms of BigLaw against their will, and then remain as a result of golden handcuffs [73]. Most students will not work in BigLaw, but they may still choose a job based largely on salary, rather than aptitude or interest. More transparency about debt and employment, along with wiser student behavior, may greatly alleviate this problem.

Happier students should make for happier faculty. But even if it does not, a correction in the salaries and perks for law school professors has been a long time coming. Tamanaha's critique of law schools [52] is at its most trenchant and powerful in the chapter on a law professor's job ("Teaching Load Down, Salary Up"), precisely because legal academics have been so slow to recognize their own role in 
the activities of the last thirty years. Law professors work less and are paid more, and yet seem mystified over why tuition and debt loads have risen so precipitously. If it is true that the worst part about living a lie is wondering when everyone will find out, the hardest part is over for legal academia.

The retrenchment will affect some law schools more than others. Top 25 and flagship state law schools will see fewer changes. Unless the ABA somehow loses its vice grip on accreditation much of law school will remain unchanged, albeit with a slightly greater focus from the ABA on skills training and clinics. This is because the ABA will have no interest in loosening accreditation standards or allowing alternative models of legal education in the teeth of the current oversupply of law graduates. Extra law graduates are good news for consumers, but the ABA is not a consumer advocacy group. It is the nation's bar association.

Even at relatively unaffected schools the waves will be felt. The law faculty that survives the retrenchment will, like the students who are happy to be employed, experience gratitude for what they have, rather than jealousy for what they do not. The mania of rankings competition and lateral professor hiring will also slow, all increasing satisfaction.

\subsection{The Harder Case - Legal Practice Will Be Better}

Today's law students will also enter a significantly changed practice, but a practice much more likely to generate satisfaction. The coming changes in BigLaw are the clearest example.

\subsubsection{The BigLaw System and Happiness}


From the turn of the twentieth century and into the 1950s, large American law firms were much smaller and less lucrative than they have been over the last 40 years. The gap in pay between law firm partners and the rest of the profession was likewise much smaller [7].

Marc Galanter and Thomas Palay called the late-50s and early 60s the "golden age" for large American law firms [74]. ${ }^{7}$ In the 1950s and 60s law firms grew larger (although still small by todays standards) and profits grew as well [74]. Competition was at a low ebb: lawyers rarely left one firm for another and many clients were happy to stay with a single law firm in a single city. Lateral hiring was rare: the great bulk of law firm associates and partners were hired out of law school or a clerkship and stayed at the firm into partnership, or left to work at smaller firms or as in-house counsel. In comparison to the period to come, the "golden age" law firms were much less profitable. Even the largest law firms had revenues well under \$10 million [8].

As noted above, the years from 1970 to 2008 were boom times in terms of revenues, profits, the number of lawyers and the profits per partner. The irony of this story is that the halcyon days of growth were actually the worst of times for the human beings in BigLaw. In the "golden age" of law firms in the 1950s and 1960s, competition was low and loyalty was high. Lawyers stayed with one firm. They

7 This period was marked by rampant discrimination against women, African Americans, LGBT persons, and non-protestant religious groups, so no one should take it as an actual "golden age" [75]. That term refers to how these firms operated as businesses, not personnel decisions. Of course the homogeneity of a group of white protestant males may have contributed to the non-competitive nature of these firms, just as the homogeneity of Sweden or Finland may make their social structures possible. 
worked together in a partnership, building the reputational capital that Ribstein [3] recognized as so critical, and so lost, in The Death of Big Law.

I worked as a summer associate at a white shoe, Wall Street law firm in 1995. A long time partner who shared my undergraduate alma mater and had started at the firm in 1950 took me out to lunch. He described the firm to me as a family: "This firm, our clients, and the people in the firm have been my life's work," he said. He could not have been more proud of what they built and he sincerely wanted to pass that sentiment on. From the summer associate's point of view it was an amazing outpouring of emotion for what appeared to be primarily a very successful and very cutthroat moneymaking operation, and hardly a fount of familial emotions.

Most current surveys show relatively high levels of lawyer unhappiness with their careers (as well as high incidences of depression and alcoholism), with BigLaw lawyers particularly unhappy [76]. If one reflects upon the basic elements of a modern BigLaw job - constant pressure to bill more, limited control over one's schedule, reliance upon third parties (partners or clients) for career advancement, forced personal responsibility for the well-being of (frequently irascible) clients - it is not surprising that happiness rates are down.

Daniel Pink's Drive [77] offers an overview of the state of current research on motivation and career satisfaction, and offers two insights that explain the current emotional state of BigLaw, and why the golden age was likely a much happier time. First, Pink [77] defines satisfying careers along three axes: mastery, autonomy and purpose. 
Mastery refers to a career that can never be mastered and offers a lifetime of intellectual challenge. Most lawyers fit this criterion, especially in BigLaw. First year associates doing due diligence might argue, but virtually all-senior lawyers would likely agree that their work is challenging.

Purpose refers to working with a group of people towards a common and important goal. Purpose is not necessarily charity work (Drive is a book for business people), but it does require a joint sense of working together towards something. Descriptions of the golden age of law firms suggest workplaces filled with purpose, as partners and associates worked together hand in hand with their clients to create a lasting legacy. Ribstein's trenchant description of reputational capital in BigLaw describes the same effect [3]. High functioning law firms operated as partnerships in legal structure, but also in spirit.

Practicing law, even at a big firm, should lend itself to a shared sense of purpose. Lawyers work in a helping profession. This should mean a joint sense of identity as professionals, and the natural sense of purpose that comes from helping clients avoid trouble or solve problems. This sense of common purpose, or really any purpose beyond maximizing profits, is what has been diluted between the golden age firms and today's BigLaw.

But the biggest damper on BigLaw happiness is autonomy. Unlike mastery and purpose, autonomy is pretty straightforward: you need to be able to control what you do at work, with whom, and how [77]. The happiest and most productive workers have a great deal of control over the nature of their work. They are measured in their outputs, the work itself, not at how long it took them, whether 
they did the work at home or the office, etc. BigLaw runs on the exact opposite understanding and Pink [77] uses hourly lawyers as his main example of jobs that lack autonomy:

Alas, at the heart of private legal practice is perhaps the most autonomycrushing mechanism imaginable: the billable hour. Most lawyers - and nearly all lawyers in large, prestigious firms - must keep scrupulous track, often in six-minute increments, of their time. If they fail to bill enough hours, their jobs are in jeopardy. As a result, their focus inevitably veers from the output of their work (solving a client's problem) to its input (piling up as many hours as possible.

This effect accelerates as lawyers age, because lawyers in their 40 s or 50 s experience time differently than 26 year olds. I have a friend from law school that is a BigLaw partner and explains that the reality of selling his time to clients is particularly painful - the metaphor and the reality blend to make clear that what he actually sells in BigLaw is a precious part of the balance of his life.

Many lawyers of the golden age billed by the transaction or periodically "for services rendered" [74,72]. Even the hourly billing system was more civilized. Partners were paid on the basis of seniority, rather than the hours they billed or the clients they brought in [74]. Associates were measured for the quality of their work as much (or more) than for their annual billings. Because of the long term relationship between firms and clients, lawyers filled an independent counselor role [78], and had the autonomy to disagree with clients, or even call them a "damned fool" when necessary [79].

Second, BigLaw managers might take more interest in the happiness of their lawyers if they recognized Pink's [77] other primary insight. Pink gathers a series of studies on creativity and motivation to show that the motivational tools of the 
industrial age, essentially the carrots and sticks of higher pay for desired outcomes and punishments or termination for bad outcomes, have the opposite effect in jobs requiring creativity. Carrots and sticks tend to extinguish intrinsic motivation and crush creativity. They foster short-term thinking and encourage short cuts and cheating.

Pink's findings are tailor-made for BigLaw. Piling on extrinsic motivations like money and partnership, and extrinsic punishments like "up or out" partnership determinations or targeted lay offs do not motivate creative thinking. Ironically, this is exactly what corporate clients are seeking from their lawyers: not their time, but their insights. Instead, extrinsic motivations lead to unhappiness and corner cutting, with bill padding and other short cuts likely. By deemphasizing the money aspect of the job, the law firms of the past likely spurred more creativity and lawyers certainly enjoyed more job satisfaction.

In sum, over the last forty years corporate law firms changed from being the types of workplaces that humans enjoy working in - places filled with highly motivated professionals working together on intellectually stimulating joint projects with a sense of purpose - to exactly the opposite. Associates and partners work together in legal sweatshops, motivated primarily by the money, with little loyalty from the clients or to each other [80].

The current slowdown will change much of this. First, law firm partners and corporate clients have increasingly adopted alternative, non-hourly billing arrangements [81], exactly the kind of billing that encourages autonomy, efficiency and creativity. Lawyers will find working as efficiently as possible to achieve the 
best possible results on projects much more likable than grinding out as many billable hours as they can on the cases they have. Task based billing will encourage creativity and efficiency, will lessen friction with clients and will align the lawyer's interests with client's to a greater extent.

The work itself will be more interesting. Insofar as some lawyers have felt unchallenged by their work, or have been stuck doing document review or other repetitive work, the future will look quite a lot brighter [3]. The legal work that American lawyers do will be much, much more individualized, because whatever can be done by a computer or a lawyer in Bangalore for $\$ 10$ an hour will be done in that fashion. Much work will go, but the work that remains will certainly be challenging.

Axiom style alternative law firm arrangements will also blossom [82]. This will be bad news for non-lawyers working as staff in the legal sector and for commercial real estate downtown in large cities, but great news for lawyers. Clients will grow accustomed to measuring lawyers on criteria other than the mahogany in their office or the size of their staff. The "back room" expenses of BigLaw will be slashed. The lawyers working in these new "firms" will bill out less and work less, but by reducing overhead may actually make more money. This will spread beyond BigLaw as well. Small firm and solo practitioners who do not need an office or a secretary will not have one.

Alternative law firms may also be able to square the circle of increasing the representation of women at the highest rungs of the profession. Since 1990, women have made up half of American law graduates, yet as of 2010 only 20\% of BigLaw 
partners were women [83]. This is at least partially because BigLaw and the tournament of lawyers is not particularly family-friendly and women still bear the biological (and much of the psychological) burden of having and raising children. Alternative law firms offer the flexibility and autonomy to work more or less as circumstances allow and offer women lawyers the opportunity to stay in the game during times of heavy family duties.

While many lawyers will make less, the lawyers at the top will make much more. If there is one lesson of the information age and our new winner-take-all markets $[45,46]$ it is that the lawyers who find ways to deliver legal services more efficiently and cheaply, while also improving quality, will be very, very wealthy indeed. Even the wealthiest partner in the most successful American law firm does not have the earnings potential of the lawyers who founded LegalZoom. The irony of the BigLaw system is that even with all of the energy spent on leverage and billing rates and realization, it is still at heart an hourly business. It seems likely that in the future the most financially successful purveyors of legal services will not be hourly workers, but entrepreneurs.

Last, the profession itself will find this a galvanizing period. Times of dislocation bring people together, and this time will unify the legal profession as well. Lawyers and bar associations will look back on arguments about civility and professionalism with fondness as they face meetings about saving practices from on-line threats and increased competition from all sides.

In fact, it seems likely that in ten years the managing partners of large law firms and the deans of American law schools will gather over drinks to discuss with 
bemusement the rankings and other silliness that obsessed the profession during the 1990s and 2000s. Existential threats will bring needed perspective to each of our endeavors.

In short, these changes will bring a needed sense of perspective to all members of the legal profession. When the dust settles we will have a happier, healthier profession, energized by the opportunity to do the legal work that remains.

\section{CONCLUSION}

These may seem like overly optimistic predictions, but it is worth remembering that the American legal profession has survived and thrived through much more trying times. Start with De Tocqueville's [84] view of the American legal profession in the 1830s:

In the United States the lawyers constitute a power which is little dreaded and hardly noticed; it has no banner of its own; it adapts itself flexibly to the exigencies of the moment and lets itself be carried along unresistingly by every movement of the body social; but it enwraps the whole of society, penetrating each component class and constantly working in secret upon its unconscious patient, till in the end it has molded it to its desire.

Remember that this quote comes on the very eve of the greatest challenge the American legal profession has ever faced: Jacksonian Democracy and the deprofessionalization of the law [85]. In the middle of the $19^{\text {th }}$ century it looked more likely that the law would be fully open to practice by lay people than that lawyers would organize to create the profession we have today. The practice was virtually unregulated in a majority of states, and new codes of civil procedure were being introduced that also signaled the deterioration of lawyer hegemony $[85,6]$. 
After the Civil War, lawyers faced ferocious competition over the then lucrative business of conducting title searches [6]. Lawyers responded by becoming irreplaceable partners with all levels of businesses, working hand in hand with the makers of the industrial revolution. As Lawrence Friedman [6] describes the postCivil War era:

Nevertheless, the lawyers prospered. The truth was that the profession was exceedingly nimble at finding new kinds of work and new ways to do it. Its nimbleness was no doubt due to the character of the bar: open-ended, unrestricted, uninhibited, attractive to sharp, ambitious men.

Similarly, lawyers faced an existential threat during the depression, when earnings collapsed. In 1935, for example, 1500 lawyers took a pauper's oath "in order to apply to a legal relief project under the Works Progress Administration" [7]. Nevertheless, this period laid the foundation for the growth explosion from the 1950s through the 1970s for the profession as a whole, as tightened entry standards and World War II resulted in drastically reduced competition.

Hopefully the happy ending to this story will not come from further tightening of entry, but rather from a nimble profession finding its way after a few lost decades. Given the importance of lawyers in American society historically and at present, such a change would benefit all of us. 


\section{Reference List}

[1] Charles Dickens, Bleak House, Signet Classic, New York, 1980.

[2] Richard Susskind, The End of Lawyers?, Oxford University Press, Oxford, 2008.

[3] Larry E. Ribstein, The Death of Big Law, 2010 Wisconsin Law Review (2010) 749-815.

[4] Glenn Harlan Reynolds, Small is the New Biglaw: Some Thoughts on Technology, Economics, and The Practice of Law, 38 Hofstra Law Review (2009) 1-11.

[5] William Henderson, From Big Law to Lean Law, This Issue (2012).

[6] Lawrence M. Friedman, A History of American Law, Second Edition, Simon \& Schuster, New York, 1985.

[7] Richard L. Abel, American Lawyers, Oxford University Press, Oxford, 1989.

[8] Richard Sander, Hidden Transformation in the Legal Industry, ABA Young Lawyers Division, at

http://www.americanbar.org/publications/young_lawyer_home/young_lawyer_arc hive/yld_tyl_june08_sander.html (last accessed October 18, 2012).

[9] Clifford Winston, Robert W. Crandall, and Vikram Maheshri, First Thing We Do Let's Deregulate All the Lawyers, Brookings Institution Press, Washington, DC, 2011.

[10] John P. Heinz, Robert L. Nelson, Rebecca L. Sandefur, and Edward O. Laumann, Urban Lawyers, University of Chicago Press, Chicago, 2005.

[11] NALP Bulletin, Salaries for New Lawyers: How Did We Get Here?, 2008, at http://www.nalp.org/2008jansalaries (last accessed October 18, 2012).

[12] NALP Bulletin, The NALP Salary Curve Morphs with the Class of 2010, 2011, at http://www.nalp.org/salarycurve_classof2010 (last accessed October 18, 2012).

[13] ABA, Enrollment and Degrees Awarded, 1963-2011, available at http://www.americanbar.org/content/dam/aba/administrative/legal_education_a nd_admissions_to_the_bar/statistics/enrollment_degrees_awarded.authcheckdam.p df (last accessed October 18, 2012).

[14] Anne VanderMey, MBA Pay, Bloomberg Businessweek, September 9, 2009, at http://images.businessweek.com/ss/09/09/0928_mba_pay/1.htm (last accessed October 18, 2012). 
[15] Clifford Winston and Vikram Maheshri, An Exploratory Study of the Pricing of Legal Services, This Issue.

[16] Bill Henderson, Distribution of 2006 Starting Salaries: Best Graphic Chart of the Year, at http://www.elsblog.org/the_empirical_legal_studi/2007/09/distributionof.html (last accessed October 18, 2012).

[17] Nancy Rapoport, I Expect Some Law Schools to Close, at http://taxprof.typepad.com/taxprof_blog/2012/04/former-dean-rapoport-html (last accessed October 18, 2012).

[18] David McGowan, Professors Predict Law School Closings as Grads Earn Less, at http://www.nationaljurist.com/content/professors-predict-law-school-closingsgrads-earn-less-1 (last accessed October 18, 2012).

[19] Jordan Weissmann, The Death Spiral of America's Big Law Firms, The Atlantic, April 19, 2012, at http://www.theatlantic.com/business/archive/2012/04/thedeath-spiral-of-americas-big-law-firms/256124/ (last accessed October 18, 2012).

[20] Mark Harris, Why More Law Firms Will Go the Way of Dewey \& LeBoeuf, Forbes, May 8, 2012, at http://www.forbes.com/sites/forbesleadershipforum/2012/05/08/why-morelaw-firms-will-go-the-way-of-dewey-leboeuf/ (last accessed October 18, 2012).

[21] Debra Cassens Weiss, Law School applications for Fall 2012 Drop More than 15 Percent, ABA Journal, January 20, 2012, at http://www.abajournal.com/news/article/law_school_applications_for_fall_2012_d rop_more_than_15_percent/ (last accessed October 18, 2012).

[22] Jordan Weissman, The Wrong People Have Stopped Applying to Law School, The Atlantic, April 10, 2012, at http://www.theatlantic.com/business/archive/2012/04/the-wrong-people-havestopped-applying-to-law-school/255685/ (last accessed October 18, 2012).

[23] Daniel Currell and Todd Henderson, Will Lawyers Be the Prime Contractor?, This Issue.

[24] Glenn Reynolds, An Army of Davids, Thomas Nelson, Nashville, TN, 2006.

[25] Clayton Christensen, The Innovator's Dilemma, Harper Business, New York, 2011.

[26] William Henderson, Are We Asking the Wrong Questions About Lawyer Regulation?, Truth on the Market, at http://truthonthemarket.com/2011/09/19/william-henderson-on-are-we-askingthe-wrong-questions-about-lawyer-regulation/ (last accessed October 18, 2012). 
[27] Daniel Fisher, Silicon Valley Sees Gold in Internet Legal Services, Forbes, October 5, 2011, at http://www.forbes.com/sites/danielfisher/2011/10/05/silicon-valley-sees-goldin-internet-legal-services/ (last accessed October 18, 2012).

[28] LegalZoom, Inc., SEC Form S-1, at http://www.sec.gov/Archives/edgar/data/1286139/000104746912006446/a220 9713zs-1a.htm (last accessed October 18, 2012).

[29] Derek A. Denckla, Nonlawyers and the Unauthorized Practice of Law: An Overview of the Legal and Ethical Parameters, 67 Fordham Law Review (1999) 2581-2599.

[30] Unauthorized Practice of Law Comm. v. Parsons Tech. Inc., 179 F.3d 956, 956 (5th Cir. 1999).

[31] Gillian K. Hadfield, Legal Barriers to Innovation: The Growing Economic Cost of Professional Control over Corporate Legal Markets, 60 Stanford Law Review (2008) 1689- 1732.

[32] Florida Bar v. Stupica, 300 So. 2d 683, 686 (Fla. 1974).

[33] State Ex Rel. Indiana State Bar Association v. Diaz, 838 N.E.2d 433 (Ind. 2005).

[34] Gillian Hadfield, The Law-Thick World: Promoting Access to Justice through the Corporate Practice of Law, in this issue.

[35] Jonathan G. Blattmachr, Looking Back and Looking Ahead: Preparing Your Practice for the Future: Do Not Get Behind the Change Curve, 36 ACTEC Journal (2010) 1-23

[36] Michael S. Knowles, Keep Your Friends Close and the Laymen Closer: State Bar Associations Can Combat the Problems Associated with Nonlawyers Engaging in the Unauthorized Practice of Estate Planning Through a Certification System, 43 Creighton Law Review (2010) 855-81.

[37] Nathan Kopel, Seller of Online Legal Forms Settles Unauthorized Practice of Law Suit, Wall St. J., August 23, 2011, at http://blogs.wsj.com/law/2011/08/23/seller-of-online-legal-forms-settlesunauthorized-practiced-of-law-suit/ (last accessed October 18, 2012).

[38] NASDAQ OMX GlobeNewswire, Legalzoom Enters into Agreement with State of Washington, at http://www.globenewswire.com/newsroom/news.html?d=201745 (last accessed October 18, 2012). 
[39] Craig Jarvis, Online Legal Firm in Bar Fight, Charlotte News Observer, October 5, 2011, at http://www.newsobserver.com/2011/10/05/1540408/online-firm-inbar-fight.html (last accessed October 18, 2012).

[40] National Law Foundation, Practical Online Forms for Attorneys, at http://www.nlfforms.com/ (last accessed October 18, 2012).

[41] Bruce H. Kobayashi and Larry Ribstein, Law as a ByProduct: Theories of Private Law Production, 2011, at

http://papers.ssrn.com/sol3/papers.cfm?abstract_id=1884985 (last accessed October 18, 2012).

[42] Mark Greenbaum, No More Room at the Bench, L.A. Times, January 8, 2010, at http://articles.latimes.com/2010/jan/08/opinion/la-oe-greenbaum8-2010jan08 (last accessed October 18, 2012).

[43] Anika Anand, Law Grads Going Solo and Loving It, MSNBC.COM, at http://www.msnbc.msn.com/id/43442917/ns/business-careers/t/law-gradsgoing-solo-loving-it/\#.T-p2go7va9c (last accessed October 18, 2012).

[44] Leigh Jones, Vanishing Act: Year II: For the Second Year in a Row, The NLJ 250 Declined - The Biggest Two-Year Drop in the Survey's 33-Year History, Nat'l L.J., November 8, 2010.

[45] Robert H. Frank, The Economic Naturalist's Field Guide, Basic Books, New York, 2010.

[46] Robert H. Frank \& Philip J. Cook, The Winner-Take-All Society, Penguin Books, New York, 1996.

[47] Benjamin H. Barton and Stephanos Bibas, Triaging Appointed-Counsel Funding and Pro Se Access to Justice, 160 University of Pennsylvania Law Review (2012) 96794.

[48] Benjamin H. Barton, Against Civil Gideon (and for Pro Se Court Reform), 62 Florida Law Review (2010) 1227-1274.

[49] Everett M. Rogers, Diffusion of Innovations, Fourth edition, The Free Press, New York, 1995.

[50] ABA, Staff and Faculty Members, 2011, at http://www.americanbar.org/content/dam/aba/administrative/legal_education_a nd_admissions_to_the_bar/statistics/ls_staff_gender_ethn.authcheckdam.pdf (last accessed October 18, 2012). 
[51] ABA, Student Faculty Ratio, at

http://www.americanbar.org/content/dam/aba/administrative/legal_education_a nd_admissions_to_the_bar/statistics/student_faculty_ratio.authcheckdam.pdf (last accessed October 18, 2012).

[52] Brian Tamanaha, Failing Law Schools, The University of Chicago Press, Chicago, 2012.

[53] ABA, Law School Tuition, at http://www.americanbar.org/content/dam/aba/administrative/legal_education_a nd_admissions_to_the_bar/statistics/ls_tuition.authcheckdam.pdf (last accessed October 18, 2012).

[54] Ryan Lytle, 10 Law Schools That Lead to the Most Debt, U.S. News, March 22, 2012, at http://www.usnews.com/education/best-graduate-schools/the-short-listgrad-school/articles/2012/03/22/10-law-schools-that-lead-to-the-most-debt (last accessed October 18, 2012).

[55] R.H. Coase, The Problem of Social Cost, 3 Journal of Law \& Economics (1960) 144.

[56] Charles K. Whitehead, Sandbagging: Default Rules and Acquisition Agreements, 36 Delaware Journal of Corporate Law (2011) 1081-1115.

[57] Robert Cooter, The Cost of Coase, 11 Journal of Legal Studies (1982) 1-29.

[58] R.H. Coase, The Firm, the Market, and the Law, The University of Chicago Press, Chicago, 1988.

[59] Jonathan R. Macey, Transaction Costs and the Normative Elements of the Public Choice Model: An Application to Constitutional Theory, 74 Virginia Law Review (1988) 471-518.

[60] David M. Driesen \& Shubha Gosh, The Functions of Transaction Costs: Rethinking Transaction Cost Minimization in a World of Friction, 47 Arizona Law Review (2005) 61-111.

[61] Ronald J. Gilson, Value Creation by Business Lawyers: Legal Skills and Asset Pricing, 94 Yale Law Journal (1984) 239-313.

[62] Matt Leichter, New BEA Data Showing Legal Sector Grew 2.3 Percent in 2010 No Reason to Celebrate, American Lawyer, January 5, 2012, at http://amlawdaily.typepad.com/amlawdaily/2012/01/new-bea-data-show-legalsector-grew-23-percent-in-2010-no-reason-to-celebrate.html (last accessed October 18, 2012). 
[63] Derek C. Bok, A Flawed System of Law Practice and Training, 33 Journal of Legal Education (1983) 570-85.

[64] George C. Harris \& Derek F. Foran, The Ethics of Middle-Class Access to Legal Services and What We Can Learn From the Medical Profession's Shift to a Corporate Paradigm, 70 Fordham Law Review (2001) 775-845.

[65] Deborah L. Rhode, Access to Justice, Oxford University Press, New York, 2004.

[66] Robert J. Derocher, Access to Justice: Is Civil Gideon A Piece of the Puzzle?, Bar Leader, July-August 2008, at http://www.americanbar.org/content/dam/aba/migrated/legalservices/sclaid/atj resourcecenter/downloads/civil_gideon_bar_leader_article_july_2008.authcheckda m.pdf (last accessed October 18, 2012).

[67] Paul Campos, Don't Go To Law School (Unless), Amazon Electronic Books, Seattle, Washington, 2012.

[68] Angela Harris, Reforming Alone?, 54 Stanford Law Review (2002) 1449-1461. (“[T]).

[69] ABA Commission on the Impact of the Economic Crises on the Profession and Legal Needs, The Value Proposition of Attending Law School, November, 2009, at http://www.americanbar.org/content/dam/aba/migrated/lsd/legaled/value.authc heckdam.pdf (last accessed October 28, 2012).

[70] Staci Zaretsky, Cooley Law and NYLS Hot With Class Action Lawsuits, August 10, 2011, at http://abovethelaw.com/2011/08/cooley-law-gets-served-some-of-itsown-medicine-nyls-is-tardy-to-the-party/ (last accessed October 28, 2012).

[71] Law School Transparency, Overview, at http://www.lawschooltransparency.com/reform/issues/\#Overview (last accessed October 28, 2012).

[72] Chelsea Phipps, More Law Schools Haggle on Scholarships, Wall Street Journal, July 29,2012 , at

http://online.wsj.com/article/SB100008723963904441303045775571826679272 26.html (last accessed October 28, 2012).

[73] Roger E. Schechter, Changing Law Schools to Make Less Nasty Lawyers, 10 Georgetown Journal of Legal Ethics (1997) 367-90.

[74] Marc Galanter \& Thomas Palay, The Tournament of Lawyers, The University of Chicago Press, Chicago, 1991. 
[75] W. Bradley Wendel, Morality, Motivation, and the Professionalism Movement, 52 South Carolina Law Review (2001) 557-608.

[76] Nancy Levit and Douglas O. Linder, The Happy Lawyer, Oxford University Press, Oxford, 2010.

[77] Daniel H. Pink, Drive, Riverhead Books, New York, 2009.

[78] Anthony T. Kronman, the Lost Lawyer, Harvard University Press, Cambridge, 1993.

[79] Phillip C. Jessup, Elihu Root, Dodd, Mead, New York, 1938.

[80] Amanda Becker, Law Firm Associates' Job Satisfaction Down, Survey Finds, Washington Post, September 13, 2010, at http://www.washingtonpost.com/wpdyn/content/article/2010/09/10/AR2010091006548.html (last accessed October $28,2012)$.

[81] Jennifer Smith, Companies Reset Legal Costs, Wall Street Journal, April 8, 2012, at

http://online.wsj.com/article/SB100014240527023045877045773317118085721 08.html (last accessed October 28, 2012).

[82] Ashby Jones, Newcomer Law Firms are Creating Niches With Blue-Chip Clients, Wall Street Journal, July 2, 2008, http://online.wsj.com/article/SB121495897751221527.html (last accessed October 28, 2012).

[83] Ashby Jones, Why Don't Women Stay at Law Firms? Here's One Take, Wall Street Journal, March 19, 2010, at http://blogs.wsj.com/law/2010/03/19/whydont-women-stay-at-law-firms-heres-one-take/ (last accessed October 28, 2012).

[84] Alexis De Tocqueville, Democracy in America, George Lawrence translation, Doubleday Anchor J.P. Mayer, New York, 1969.

[85] Benjamin H. Barton, The Lawyer-Judge Bias in the American Legal System, Cambridge University Press, New York, 2011. 